\begin{tabular}{|c|c|}
\hline \multicolumn{2}{|c|}{ PublisherInfo } \\
\hline PublisherName & Palgrave Macmillan UK \\
\hline PublisherLocation & London \\
\hline PublisherImprintName & Palgrave Macmillan \\
\hline
\end{tabular}

\title{
International comparisons of productivity: the current and constant PPP approach
}

\begin{tabular}{|l|l|l||}
\hline \multicolumn{2}{|c|}{ ArticleInfo } \\
\hline \hline ArticleDOI & $:$ & 10.1057 palgrave.elmr.1410123 \\
\hline \hline ArticleCategory & $:$ & Feature \\
\hline \hline ArticleFirstPage & $:$ & 33 \\
\hline \hline ArticleLastPage & $:$ & 39 \\
\hline \hline & & RegistrationDate $: 2007-8-17$ \\
ArticleHistory & $:$ & OnlineDate $\quad$ 2007-8-17 \\
\hline \hline ArticleCopyright & $:$ & Crown copyright2007 \\
\hline \hline
\end{tabular}




\section{Sumit Dey-Chowdhury, ${ }^{\text {Affl }}$}

\section{Explains the differences between the two approaches, outlining the context in which they should be used.}

The purpose of this article is to explain the differences between the current and constant purchasing power parity (PPP) approaches to producing estimates of international comparisons of productivity. This aims to outline and explain the context in which the respective approaches should be used. The Office for National Statistics (ONS) recommends that, for assessing differences in productivity levels, the current PPP approach should be used. For comparing differences in productivity growth across countries, the constant PPP approach should be used. This article marks the first time that ONS has produced volume growth rates for these productivity data using the constant PPP approach. These are presented towards the end of this article.

The Full Text of this article can be found on the National Statistics website (http://www.statistics.gov.uk/elmr/08_07/downloads/ELMR08_07Dey-Chowdhury.pdf). 